\title{
高層 RC 建物の地震応答シミュレーション解析と深部地盤構造の影響 EARTHQUAKE RESPONSE SIMULATION ANALYSIS OF HIGH-RISE RC BUILDING AND EFFECT OF DEEP SUBSURFACE STRUCTURE
}

\author{
永野正行*, 山田有孝**, 辻 幸二***, 小田 聡**** \\ Masayuki NAGANO, Ariyoshi YAMADA, Koji TSUJI \\ and Satoshi ODA
}

\begin{abstract}
This study investigates earthquake response characteristics of a high-rise reinforced concrete building constructed within the damage belt of Kobe City during the 1995 Kobe earthquake. Weak nonlinearity is inferred from the top and base records of the building during the 2000 Tottori-ken Seibu earthquake. After dynamic parameters of the building are tuned up, the records in the building are well simulated in nonlinear earthquake response analyses. Then, the ground motions in the neighboring area are evaluated taking into account the deep subsurface structure. The seismograms obtained at GL-300m beneath the building and at the mountain area are well simulated from records on ground surface adjacent to the building. Finally, the effects of the deep subsurface structure on the seismic response of the building are studied, which is not negligible because of ground motion amplification in the basin-edge structure.
\end{abstract}

Keywords: $\quad$ high-rise building, recorded motion, earthquake response, nonlinear, deep subsurface structure, 2000 Tottori-ken Seibu earthquake 高層建物、観測記録、地震応答、非線形、深部地盤構造、2000年鳥取県西部地震

\section{1.はじめに}

1995 年兵庫県南部地震では神戸市街地を中心として東西方向の 広い範囲で家屋等が壊堿的な被害を受け、いわゆる「震災の帯」 が形成された。一方、新而震設計法以降の建築物に関しては顕著

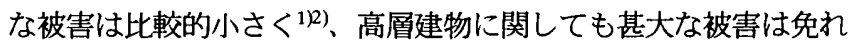
ていた刚えばこことが報告されている。特に「震災の帯」内に建って いた高層建物に関しては、その被害は比較的軽微であることが報 告されており4)、埋め込み基礎による地震動の入力低減効果も指摘 されている5)。震災後は都市復興を目指し住宅を中心亡した再開発 が進行しており、高層建物もいくつか建設されている。この中に は地震観測を実施している建物もあり、ここで得られる観測記録 は、「震災の帯」の一因とされる深部地盤構造による地震動増幅㓚 えは化と、高層建物の地震時挙動との関係を把握する上で貴重な基礎 資料となる。本論文は神戸市街地に建つ高層 RC 住宅を検討対象と して強震記録のシミュレーション解析を行うとともに、神戸市街 地直下の深部地盤構造による地震動増幅が建物の地震応答特性に 与える影響を検討したものである。

2000 年 10 月 6 日には鳥取県西部地震（M 7.3 、北緯 $35.3^{\circ}$ 、東 経 $133.4^{\circ}$ 、深さ $11 \mathrm{~km}$ ） が発生し、K-net ${ }^{7)} 、$ KiK-net ${ }^{8)}$ を含む多く の地点で地震動が観測された。長周期成分が卓越していたごとか
ら、震源からかなり離れた場所に建つ高層建物の観測記録や検討 例がいくつか報告されている910)。神戸市街地でも震度 4 を記録し、 いくつかの地点で観測記録が得られた。本研究で検討対象とする 高層建物でも、計測開始以来最も大きな最大加速度の地震記録を 観測した。建物内には地震計が 3 フロアに設置されているほか、敷 地内の地表面と直下深さ $300 \mathrm{~m}$ 位置での地震観測が実施されている。 これらの記録を分析し、シミュレーション解析を実施することに より、高層建物の地震時挙動を詳細に調べることが出来る。また 地盤上や地中で得られた観測記録も併せて検討することにより、 深部地盤の地形効果による地震動増幅特性や建物応答に与える影 響を定量的に把握することができ、今後の地震防災へ反映させる ことができる。

本論文では最初に 2000 年鳥取県西部地震時に得られた観測記録 を分析後、建物内で得られた観測記録に整合する多質点曲げせん 断モデルを構築する。次に当該建物を通り六甲断層系に直交する 方向で、六甲花崗岩から成るせん断波速度 $3 \mathrm{~km} / \mathrm{s}$ 以上の地震基盤

（以降、簡単に基盤と呼称。）の不整形性を考慮した深部地盤モ デルを作成し、地表や地中で得られた観測記録のシミュレーショ ン解析を行う。最後に深部地盤の基盤不整形性による地震動増幅 が、高層建物の地震時挙動に与える影響を評価する。
* 鹿島小堀研究室 博士 (工学)

** 鹿島小堀研究室

*** 鹿島関西支店建築設計部

**** 都市基盤整備公団総合研究所技術センター
Kobori Research Complex, Kajima Corporation, Dr. Eng.

Kobori Research Complex, Kajima Corporation

Architectural \& Engineering Department, Kansai Branch, Kajima Corporation

Technology. Center, Urban Development Corporation Research Institute 


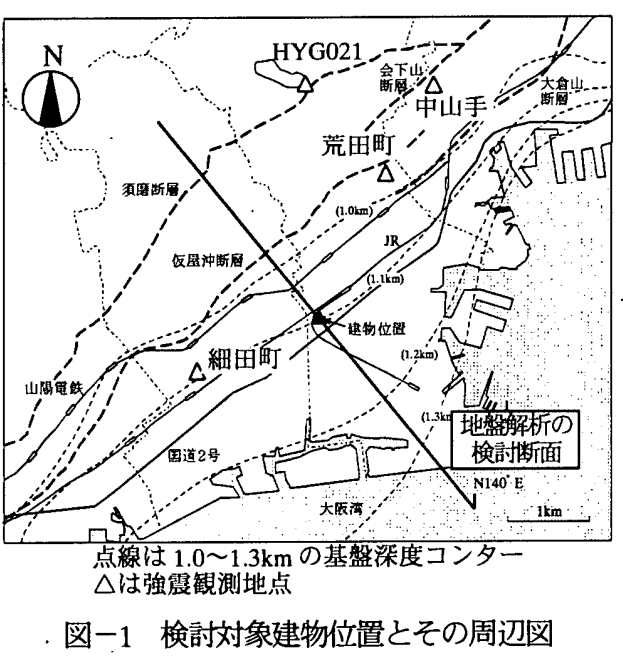

\section{2、建物、観測概要と観則記録}

対象とする建物は、神戸市街地に建つ地下 1 階、地上 37 階の $\mathrm{RC}$ 建物である。建物位置を図一 1 に、建物概要を図 -2 に示す。 平面の主軸方向はほぼ NS、EW 方向と一致するため、以降の解析 結果は NS、EW 方向で統一する。正方形に近い平面形状の一辺は 約 $30 \mathrm{~m}$ 、軒高は約 $109 \mathrm{~m}$ であり、設計時の地上部総重量は約 37800ton である。各方向ともに主に 4 列のフレームで水平力に抵 抗する。設計畤の基礎固定モデルの固有周期は、 1 次 2.06 秒、2次 0.66 秒、3次 0.30 秒で、両方向で同じである。地下部は $7.5 \mathrm{~m}$ の埋 め込みを有する杭基礎であり、杭先端は深さ GL-22m 位置にある 洪積砂層に支持される。

强震矍測は建物内では 36F、14F、1F の 3 点、地盤内では建物 から約 $7 \mathrm{~m}$ 離れた地表面（GS）之建物直下 GL-300m で行われて いる。36F と $14 \mathrm{~F}$ の地震計は建物の隅部に設置されているが、設 計モデルによる地震応答解析の結果、並進方向入力時のねじれの 影響は小さいことを確認しており、これらの記録は重心位置とほ ほ同じ並進応答と見なすことができる。2000 年鳥取県西部地震時 に観測された建物と地盤の最大加速度、最大速度を表-1に、36F、 1F、GL-300m で得られた NS 方向の加速度応答スペクトルを図一 3 に示す。1F、GL-300m については振幅を 5 倍に抁大した。36F の最大加速度、速度は $1 \mathrm{~F}$ に対し 4 倍以上增幅している。1F、GL$300 \mathrm{~m}$ の応答スペクトルを見ると 1 秒より長周期側の地震動成分が 比較的大きくなっており、震源深さが浅い 2000 年鳥取県西部地震 時の各地の観測喰録に見られる傾向 ${ }^{11}$ と整合する。

$1 \mathrm{~F}$ に対する $36 \mathrm{~F}$ のフーリエ振幅比を図 -4 に示す。同図には 2000 年鳥取県西部地震と、それ以前に観測された小振幅の 7 地震 記録から評価したフーリエ振幅比を比較した。7地震中、36F の最 大応答加速度は $24 \mathrm{~cm} / \mathrm{s}^{2}$ であり、鳥取県西部地震時に比べ約 $1 / 3$ の 振幅レベルである。 $\nabla$ で示す鳥取県西部地震以前の結果に比べやや長周期化しており、 建物がやや非線形領域に入ったことを示唆する。

\section{3. 建物内観測記録のシミュレーション解析}

\section{1 建物のモデル化}

各方向 8 本の曲げせん断系多質点モデルで上部フレーム構造を
表-1 2000 年鳥取県西部地震時の観 测記録の最大值一覧

\begin{tabular}{|c|c|c|}
\hline $\begin{array}{c}\text { 観測 } \\
\text { 位置 }\end{array}$ & $\begin{array}{c}\text { NS 方向 } \\
\text { Amax (Vmax) } \\
\mathrm{cm} / \mathrm{s}^{2}(\mathrm{~cm} / \mathrm{s})\end{array}$ & $\begin{array}{c}\text { EW 方向 } \\
\text { Amax (Vmax) } \\
\mathrm{cm} / \mathrm{s}^{2}(\mathrm{~cm} / \mathrm{s})\end{array}$ \\
\hline $36 \mathrm{~F}$ & $89.1(26.2)$ & $70.4(17.8)$ \\
\hline $14 \mathrm{~F}$ & $52.2(11.8)$ & $36.7(6.8)$ \\
\hline $1 \mathrm{~F}$ & $19.8(4.7)$ & $17.5(3.9)$ \\
\hline $\mathrm{GS}$ & $18.1(4.9)$ & $18.5(4.1)$ \\
\hline $\mathrm{GL}-300 \mathrm{~m}$ & $12.4(3.0)$ & $9.0(1.6)$ \\
\hline
\end{tabular}

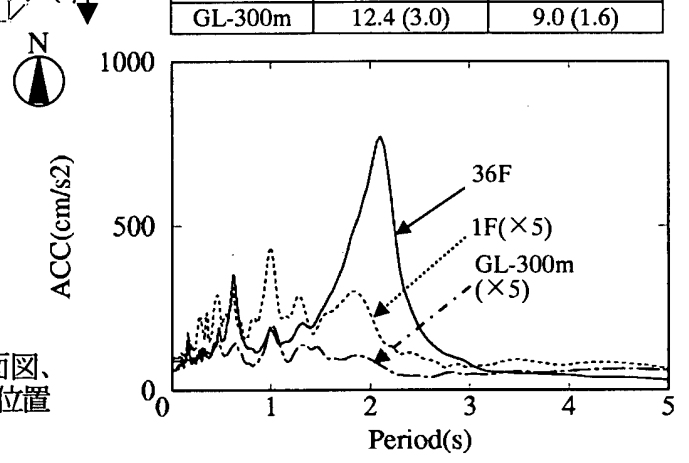

図ー3 2000 年鳥取県西部地震時に観測された波形 の加速度応答スペクトル（NS 方向）

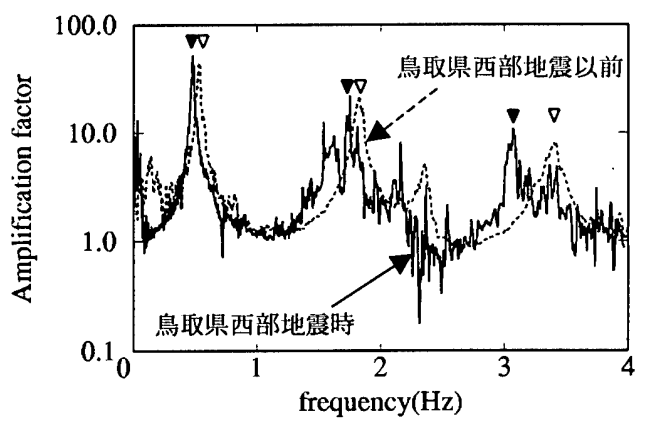

図ー4 観測記録から評価した $1 \mathrm{~F}$ に対する $36 \mathrm{~F}$ のフ 一リ工振幅比

表現し、各フロアレベルの並進自由度を剛床仮定することにより、 3 次元挙動を擬似的に表現した ${ }^{12}$ 。振動解析モデルを図 -5 に示す。 最初に柱、梁、パネルより構成される設計用の 3 次元立体骨組モデ ルに、 $\mathrm{A}$ 分布に基づく地震荷重を各階の重心位置に作用させ、1階 柱脚位置を固定条件とした静的非線形漸增解析を行った。柱部材 には RC 塑性論に基づく非線形特性13)を、梁部材には3折れ線近似 した非線形特性を設定した。線形領域における各フレーム、各層 の層間变形を曲げ变形、せ九断変形に分離し、初期曲げ、せん断 剛性を評価した。次に潮增解析より得られた層せん断力一せん断 変形角の非線形骨格曲線を、3 折れ線で近似した。解析結果の一例 を図一6に示す。第一降伏点は、当該層上下の梁部材端部の多くが 曲げひび割れモーメントに達する層せん断力（ベースシア保数は 約 0.03）に対応する。第二降伏点は、当該層上下梁の曲け降伏が 進行する層せん断力（ベースシア係数は約 0.14）に対応する。初 期剛性に対する第 2 剛性の接線剛性低下率は、0.25 0.30 である。 上部フレーム構造と埋め込み杭基礎、地盤との動的相互作用を 考慮するため、基礎床付け位置(GL-7.5m)に水平、ロッキング、ね じれの地盤ばねを付与した。動的インピーダンスは、基礎埋め込 み部一杭一地盤を図ー7 に示す軸㸚称有限要素法 ${ }^{(4)}$ でモデル化し評 価した。地盤物性は建物直下の PS 検首テータを用い、下部の半無 限層はS 波速度 $0.45 \mathrm{~km} / \mathrm{s}$ とした。深さ $300 \mathrm{~m}$ 位置までの地盤の速 度構造 ${ }^{15)}$ によれば $\mathrm{S}$ 波速度 $0.45 \mathrm{~km} / \mathrm{s}$ の首以深では同等のせん断波 


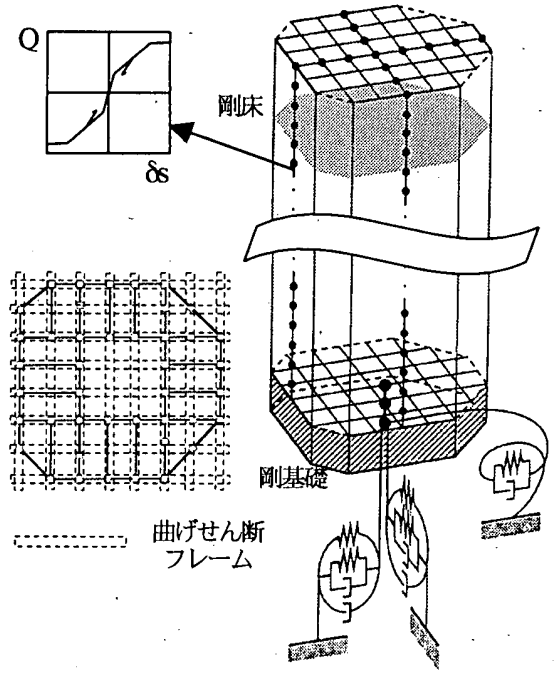

図-5＼cjkstart建物の解析モデル

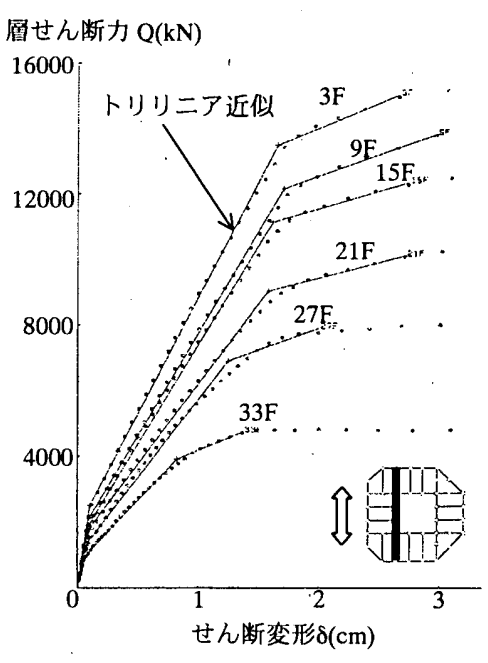

図-6 静的漸增解析結果の一例

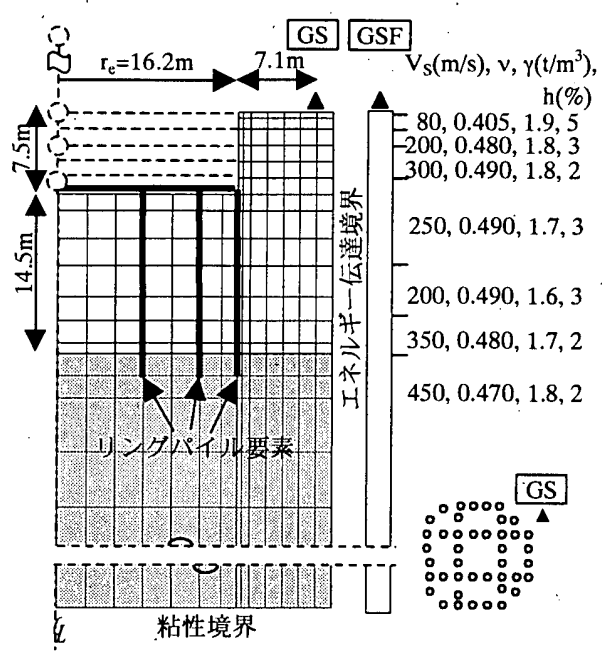

図一7 埋め込み杭基礎一地盤の軸対 称有限要素モデル
速度の層厚が大きいため、より深部の地層が地盤ばね評価に及ぼ す影響は小さいものと考えられる。また鳥取県西部地震の GS の記 録を用い 1 次元重複反射理論で評価した表層地盤の平均的な最大㐫 答せん断ひずみは約 $3 \times 10^{-5} \mathrm{rad}$ であったため、非線形性によるせ ん断波速度の低減は小さいものと判断した。上部建物一地盤連成 系の 1 次固有振動数に近い $0.5 \mathrm{~Hz}$ 時の実部より地盤ばねを、虚部 の傾きより粘性減衰係数を評価した。算定した地盤ばね值を表 -2 に示す。

\section{2 線形挙動時のシミュレーション解析.}

2000 年鳥取県西部地震以前に得られた小振幅の地震記録に対し シミュレーション解析を実施し、建物線形時の剛性、減衰を評価 した。ここでは、1 次固有振動モードが比較的大きく励起された地 震（2000 年5月 16 日、京都・大阪府境地震、 $\mathrm{M}_{\mathrm{J}} 4.3$ 、北緯 $35.0^{\circ}$ 、 東経 $135.5^{\circ}$ 、深さ $16 \mathrm{~km}$ ）時の観測記録を対象とした。

最初に 3.1 で設定した解析モデルに対し、上部建物の曲け㟠性 EI、 せん断剛性 GA を変動させ、図一4のフーリ工振幅比に見られる共 振振動数と整合するように設定した。3 次モードまでの共振ピーク を整合させた結果、EI を一律 1.3 倍、GA 1.5 倍とした。観測に よる剛性評価が大きい要因として、(1)コンクリートの材料強度や 弾性係数が設計時に比べ大きいこと ${ }^{16)}$ 、(2)設計時の立体骨組モデル で考慮されていない非構造部材である外壁、戸境壁、小梁等の剛 性の影響、等が挙げられ、(1)により EI、GA の両者が、(2)により GA が設計值より大きくなったものと推察される。実測による高層 建物の固有周期は設計用モデルに対し 2〜4 割程度短いことが既往 の研究 ${ }^{17)}$ で示されており、本解析モデルの剛性評価はこの傾向之対 応する。基礎底面に地盤ばるをつけた連成モデルの固有周期は 1 次 1.93 秒、2 次 0.56 秒、3次 0.30 秒であり、 1 階基礎固定モデルの 1 次固有周期 1.73 秒に対し、1 割程度周期が変化する。1 次固有モ一 ドの建物頂部变形に占める地盤变形の割合は、水平方向が約 $2 \%$ 、 ロッキング回転が約 $18 \%$ であり、後者の影響が大である。次に観 測記録の応答波形、応答スペクトルと整合するように減衰特性を 設定し、 1 次固有周期に対し $0.2 \%$ の内部粘性减衰を仮定した。地

\begin{tabular}{|c|c|c|}
\multicolumn{4}{c}{ 表 -2 地盤ばね一覧 } \\
\hline & 地盤ばね & 減衰係数 \\
\hline 水平方向 & $2.10 \times 10^{7} \mathrm{kN} / \mathrm{m}$ & $6.69 \times 10^{5} \mathrm{kNs} / \mathrm{m}$ \\
\hline 回転方向 & $1.09 \times 10^{10} \mathrm{kNm} / \mathrm{rad}$ & $6.93 \times 10^{7} \mathrm{kNms} / \mathrm{rad}$ \\
\hline ねじれ方向 & $4.45 \times 10^{9} \mathrm{kNm} / \mathrm{rad}$ & $2.83 \times 10^{7} \mathrm{kNms} / \mathrm{rad}$ \\
\hline
\end{tabular}

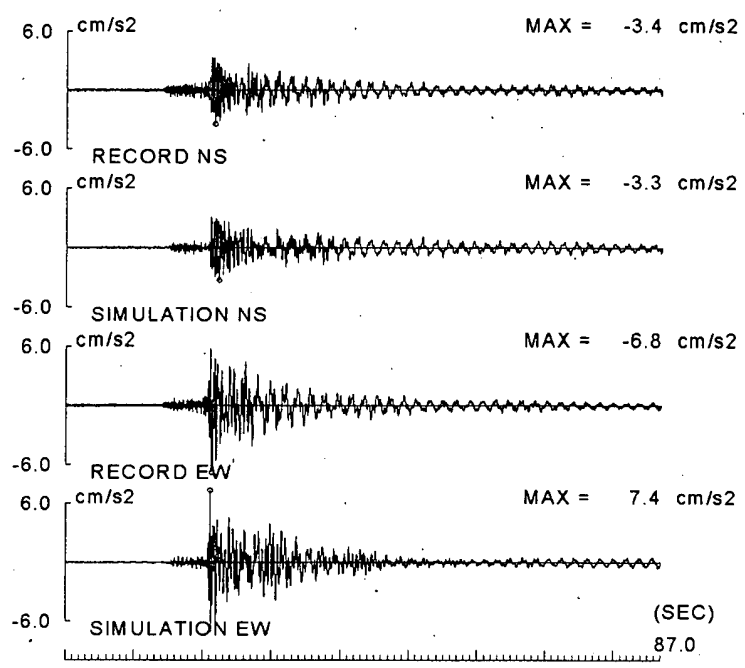

(a) 応答加速度波形 (36F、EW 方向)

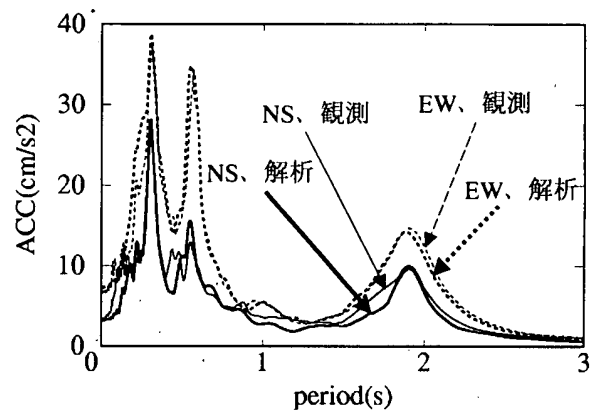

(b) 加速度応答スペクトル $(\mathrm{h}=3 \%)$

図 -8 建物線形挙動時のシミュレーション解析による $36 \mathrm{~F}$ の応答加速度波形と加速度応答スペクトル

震応答解析では 1 階床位置のロッキング変形を許容した状態で、 1F の観測記録を NS、EW の 2方向に同時入力した。解析時間刻夕 
は 1/100s.とした。1F の観測記録を入力したときの 36F のシミュ レーション加速度波形と加速度応答スペクトルを、観測記録と比 較して図-8 に示す。最大值に若干の差異は見られるものの解析に よる加速度波形は観測記録と概ね一致する。また応答スペクトル についても、観測に見られる3次モードまでのピーク周期、スペク トル值は、シミュレーション解析により良好に再現される。

\subsection{0 年鳥取県西部地震のシミュレーション解析}

2000 年鳥取県西部地震時の非線形シミュレーション解析を実施 する。弾性時の剛性は 3.2 で設定した值を用いる。第一、第二降伏 点のせん断力については、主に観測記録の応答スペクトルの卓越

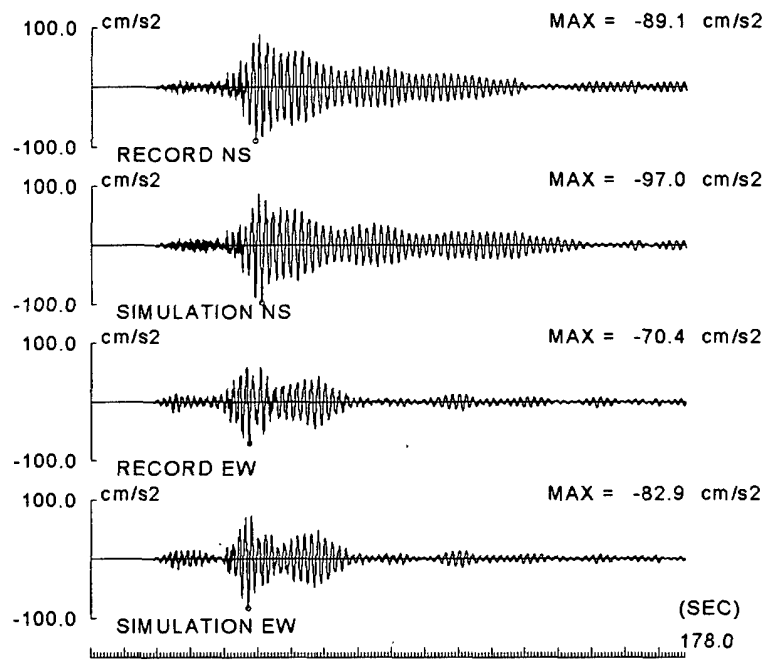

(a) 応答加速度波形

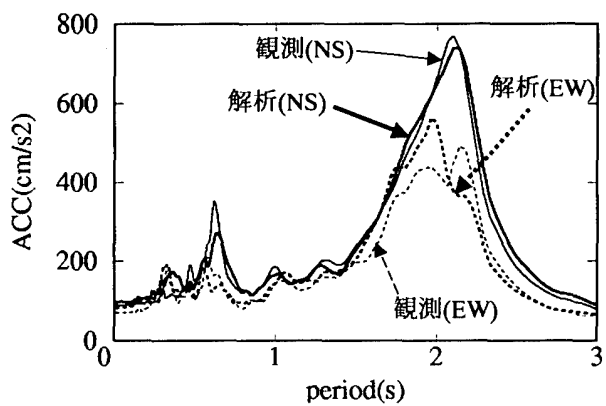

(b) 加速度応答スペクトル $(\mathrm{h}=3 \%)$

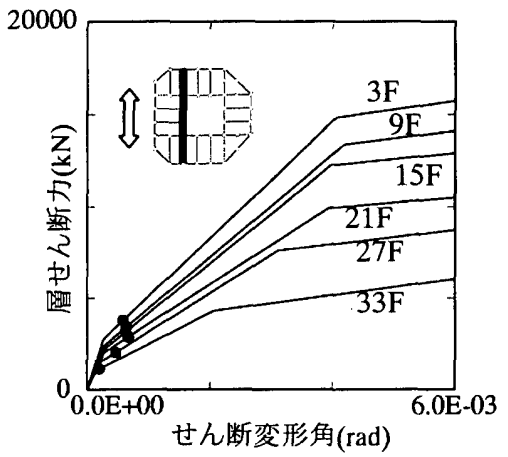

(c) 骨格曲線と最大応答点

図-92000 年鳥取県西部地震観測記録のシミュレーシ ヨン解析による $36 \mathrm{~F}$ の応答加速度波形と加速度応 答スペクトル、主要フレームの最大応答点
周期と整合するように、3.1 で設定した值を基に調整した。減衰特 性については主に応答スペクトルのピークと整合するように設定 し、最終的に $14 \mathrm{~F} 、 36 \mathrm{~F}$ における両方向の観測加速度波形との対応 を確認しながらこれらのパラメータを決定した。この結果、第一、 第二降伏点のせん断力を 3.1 で設定した值の一律 1.1 倍とし、剛性 劣化型の履歴特性を与えた。また減衰機構としてレイリ一型減衰 を仮定し、弾性時 1 次、2 次固有周期の減衰定数を $1.3 \%$ とした。 応答解析法は 3.2 と同じであるが、非線形解析であることを考慮し て時間刻みを $1 / 500 \mathrm{~s}$.とした。1F の観測記録を入力したときの $36 \mathrm{~F}$ のシミュレーション加速度波形と加速度応答スペクトルを観測記 録と比較して図一9(a)(b)に示す。最大值やスペクトルピーク值に やや差異が見られるものの、シミュレーション解析により観測記 録が概ね良好に再現されている。主要フレームの最大応答值を骨 格曲線上にプロットして図一9(c)に示す。最大応答変形時の割線剛 性低下率の平均は約 0.8 であり、これは図-4のフーリ工振幅比か ら示唆される周期の変化（約 10\%）と概ね対応する。

実測より評価される建物の剛性や而力、減衰特性が、設計時の 解析モデルと異なることは従来から指摘されており ${ }^{17) ~}{ }^{18)}$ 、本解析 結果においても設計時の解析モデルでは、地震時挙動の正確な予 測が難しいことを示している。観測記録との対応による解析検証 の積み上げが、建物の合理的な耐震設計手法を確立する上で重要 となる。一方で 1995 年兵庫県南部地震時の建物のシミュレーショ ン解析結果と被害状況、入力地震動との関係も、完全に整合した

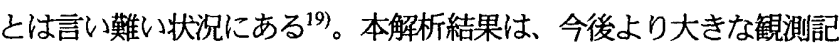
録が得られた場合に、建物の耐力、変形性能を含む動特性を議論 する際の基礎資料として位置付けられる。

\section{4. 地盤で得られた観則記録のシミュレーション解析}

\section{1 深部地盤構造のモデル化}

神戸市街地值下の深部地盤は盆地端部構造となっており、1995 年兵庫県南部地震時の地震動増幅に影響を及ぼした利えば6)。また当 該地点の近くの長田区で実施された余震アレ一観測記録のシミュ レーション解析では、深部地盤構造による地震動増幅が観測、解 析の両方から確認されており もその影響が入っているものと考えられる。ここでは 2次元有限要 素法(FEM)を用いて基盤不整形性を考慮した深部地盤構造の地盤 応答を算定し、GL-300m を含む地盤系の観測記録を対象に 2000 年鳥取県西部地震のシミュレーション解析を行った。

長田区から兵庫区の深部地盤構造は、断層平行方向で基盤深度 の変化がやや見られるものの、ほぼ2次元的な基盤形状を呈する。 前述の長田区のシミュレーション解析断面は建物建設地点に近接 しており、余震アレ一観測記録のシミュレーション解析により地 盤構造の妥当性が検証されている。このときの地盤モデルをべー スに、図ー 1 に示した当該地点を通り六甲断層系に直交する断面 （N140 E）で地盤モデルを作成した。当該地点では建物直下の 速度構造（図一7）のほかに、敷地内で深さ $300 \mathrm{~m}$ 位置までの PS 検層が実施されている15)。図一7の動的インピーダンス等の検討で は地表近傍地盤の影響を考慮して細かい地層構造までモデル化し たが、これを数 $\mathrm{km}$ に及ぶ領域の深部地盤モデルに反映させること は難しい。このため深さ $297 \mathrm{~m}$ の $\mathrm{V}_{\mathrm{S}}=880 \mathrm{~m} / \mathrm{s}$ 地層上面より浅い地 


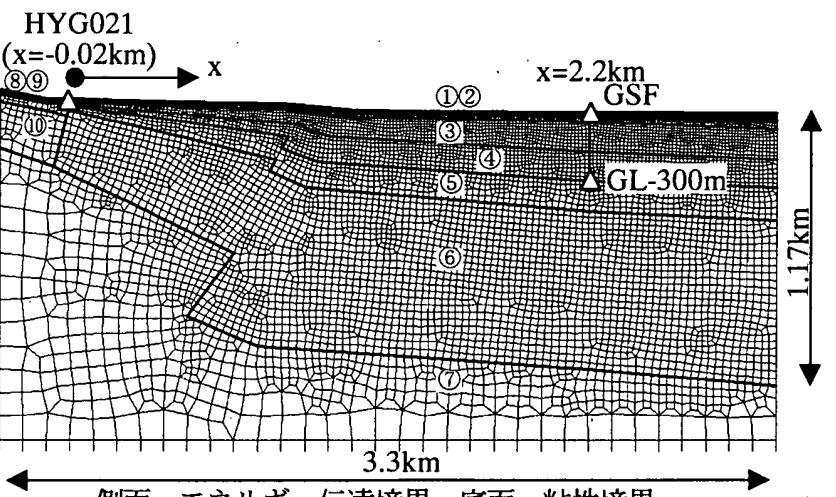

側面 : エネルギー伝達境界、底面 : 粘性境界

図-102次元解析に用いた地盤モデル

表一3 2次元解析モデルに用いた地盤物性

\begin{tabular}{|c|c|c|c|c|c|}
\hline No. & $\begin{array}{c}\mathrm{S} \text { 波速度 } \\
\mathrm{m} / \mathrm{s}\end{array}$ & $\begin{array}{c}P \text { 波速度 } \\
\mathrm{m} / \mathrm{s}\end{array}$ & $\begin{array}{l}\text { 密度 } \\
\mathrm{t} / \mathrm{m}^{3}\end{array}$ & 減衰定数 & $\begin{array}{l}\text { 当該地点 } \\
\text { 直下の上 } \\
\text { 面深さ m }\end{array}$ \\
\hline (1) & 227 & 1521 & 1.9 & 0.030 & 0 \\
\hline (2) & 418 & 1954 & 2.0 & 0.020 & 19 \\
\hline (3) & 531 & 1888 & 2.0 & 0.020 & 44 \\
\hline (4) & 618 & 1873 & 2.0 & 0.020 & 169 \\
\hline (5) & 880 & 2270 & 2.0 & 0.015 & 297 \\
\hline (6) & 1000 & 2500 & 2.1 & 0.015 & 425 \\
\hline (7) & 3200 & 5400 & 2.7 & 0.010 & 1105 \\
\hline (8) & 380 & 730 & 2.0 & 0.020 & - \\
\hline (9) & 680 & 1580 & 2.2 & 0.020 & $=$ \\
\hline (10) & 1350 & 3100 & 2.2 & 0.015 & - \\
\hline
\end{tabular}

層構造を $\mathrm{V}_{\mathrm{S}}$ がほぼ同等の 5 層構造にまとめ平均化し、これを 2 次 元モデルの地盤物性に適用した。これより深い地盤物性は既往の シミュレーション解析モデル (6)20)を参考に決定した。盆地端部に相 当する須磨断層や伏在断層の位置、形状は、地盤調査結果 ${ }^{2122223)}$ 参考に設定した。検討対象地点は須磨断層より $2.2 \mathrm{~km}$ 離れた位置 とした。山側の地盤構造は須磨断層直上に位置する K-net 観測点

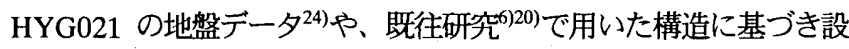
定した。地盤モデルを図ー10に、地盤物性を表一 3 に示す。FEM のメッシュは $5 \mathrm{~Hz}$ 時の $\mathrm{S}$ 波 1 波長を 6 メッシュ程度で表現できる ように分割し、 $5 \mathrm{~Hz}$ までの周波数応答解析を実施した。

\section{2 地表面観測記録に含まれる建物挙動の影䈉の除去}

地表面観測記録(GS)は建物に近接して設置されているため、高 層建物－基礎系の振動による影響を受けていると考えられる。そ こで図ー7に示した軸対称 FEM に建物モデルを付け加え、GS の地 震記録から建物振動の影響を除去した自由地表面位置の応答（以
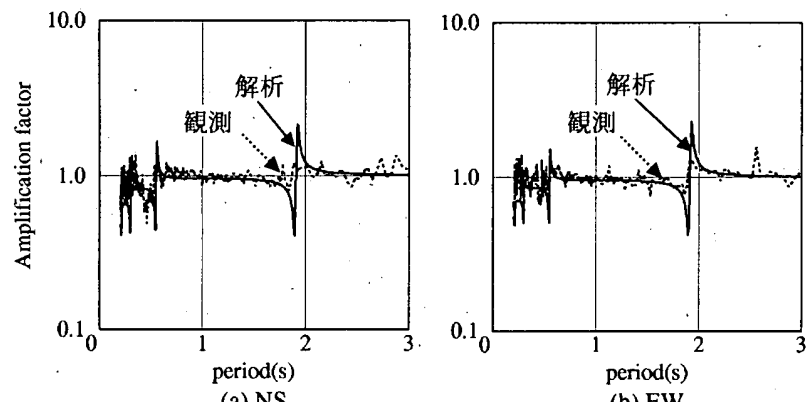

(a) NS

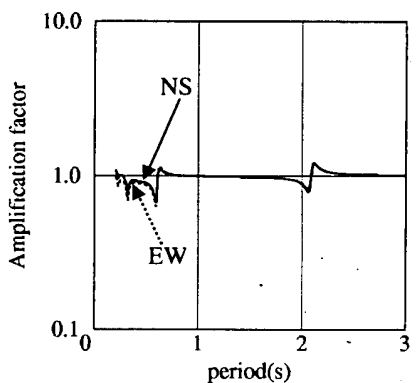

(a) GS/GSF

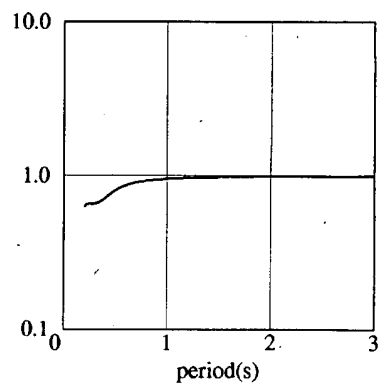

(b) INPUT MOTION /GSF

図-12，GSFに対する GS と基礎入力動の伝達関数

下、GSF と呼称。）を算定した。参考までに建物線形時の 1F/GS の伝详関数を、図 4 と同じ小振幅の 7 地震記録から評価したフー リ工振幅比と比較して図ー11 に示す。観測記録の傾向は解析によ り捕えられている。

軸対称 FEM は線形解析であるため、鳥取県西部地震時の建物の 非線形挙動を等価的に表現する必要がある。ここでの目的が GS の 観測記録から建物応答の影響を除去することであるため、等価剛 性、減衰によって建物の非線形挙動を評価する簡便な手法をとつ た。フレーム剛性は 3.1 で設定した建物モデルに対し EI を 1.0 倍、 $\mathrm{GA}$ を 1.3 倍とし、減哀は $3 \%$ の履歴减衰とした。フレーム剛性は 前述の鳥取県西部地震時の剛性低下率と概ね対応する。等価線形 解析により $1 \mathrm{~F}$ の観測記録を入力して評価した $14 \mathrm{~F} 、 36 \mathrm{~F}$ の加速度 波形、加速度応答スペクトルが、観測記録と概ね良好に対応する ことを別途確認している。この解析モデルにより得られた図一 12(a)に示す GS／GFS の伝達関数を用いて、GSF の地震動を評価 した。1 次固有周期と短周期側で建物応答の影響が GS の伝達特性 に若干現れることが分かる。

\section{3 観測記録のシミュレーション解析}

図一10 の深部地盤モデルを用いて SV 波、SH 波鈶直入射解析を 行い、GSF の地震動を用いて GL-300m 位置の地盤応答を評価し た。SV 波入射時の応答は断層直交方向 $\left(\mathrm{N} 140^{\circ} \mathrm{E}\right) 、 \mathrm{SH}$ 波入射時 の応答は断層平行方向 $\left(\mathrm{N} 230^{\circ} \mathrm{E}\right)$ の地盤応答として評価し、これら の波形を回転変換し NS、EW 方向の地盤応答を求めた。震源から 発生し当該地域に伝播する複雑な地震波動を厳密に評価するには、 震源から神戸の地盤構造を一体とした解析検討が必要となる。し かしながら建物の3次モードまでの振動数を考慮した計算は現状で は困難であり、また斜め入射を検討する場合もSV 波入射時には臨 界角を超え挙動の変化が大きくなる可能性があることから、ここ では簡単に面内、面外の波動伝播を組み合わせた鈶直入射により 地盤増幅特性を評価した。

GL-300m のシミュレーション速度波形、5\%擬似速度応答スペ クトルを観測記録と比較して図ー13 に示す。GSF の地震動を用い たシミュレーション解析によって、GL-300m の観測記録が波形、 スペクトルともに概ね良好に再現される。次に GSF から須磨断層 のほぼ值上に位置する HYG021 の地盤応答を算定し:シミュレー ション解析を行った。算定した速度波形と擬似速度応答スペクト ルを観測記録と比較して、図一14 に示す。NS 方向では観測波形の 全般的な特徴や、スペクトル特性の傾向は解析により概ね良好に 


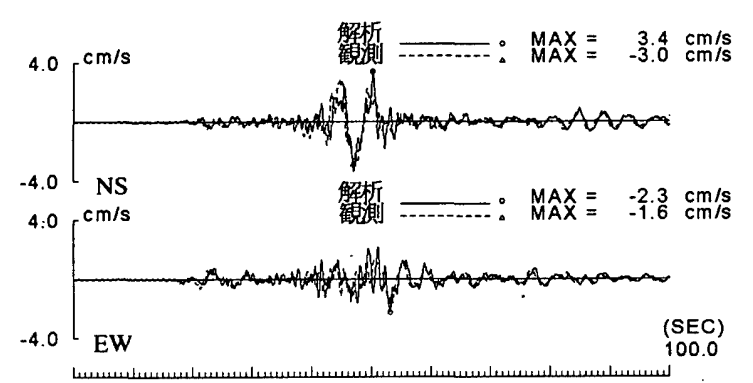

(a) 速度波形
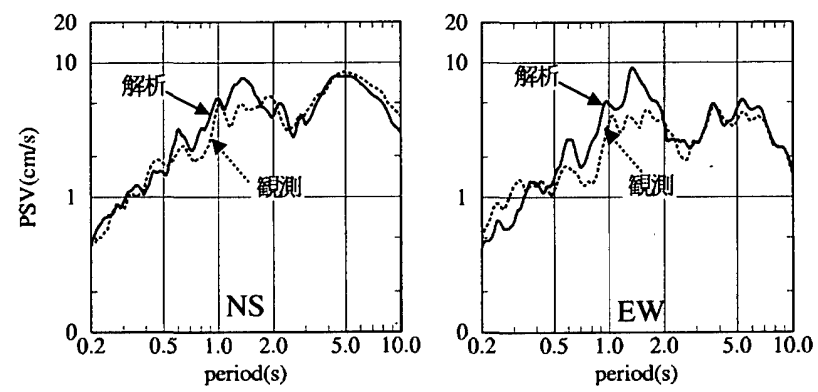

(b) 擬似速度応答スペクトル $(\mathrm{h}=5 \%)$

図-13 シミュレーション解析による GL-300m の速度 波形と応答スペクトル

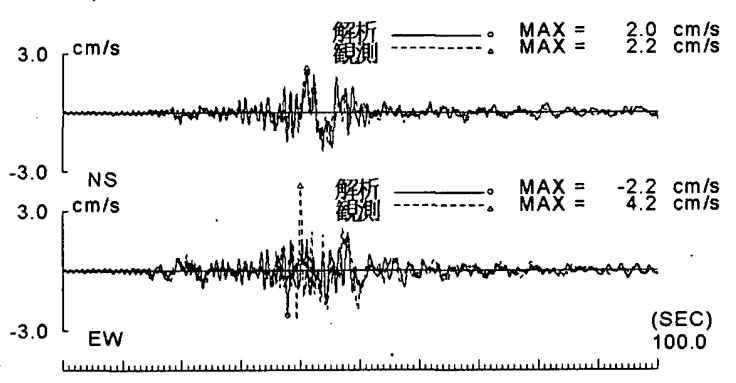

(a) 速度波形
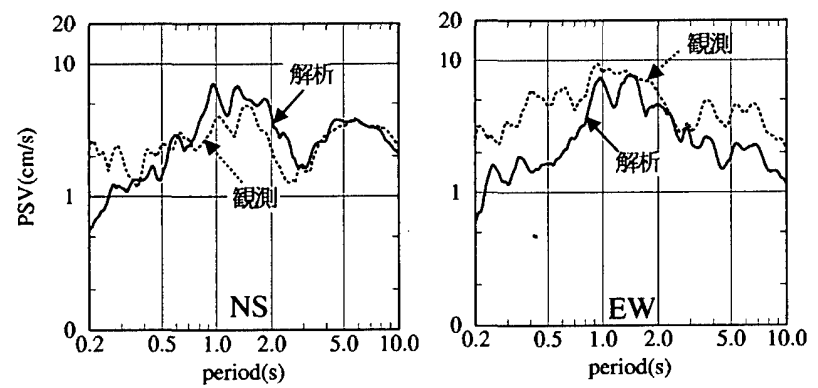

(b) 擬似速度応答スペクトル $(\mathrm{h}=5 \%)$

図-14 シミュレーション解析による HYG021 の速 度波形と応答スペクトル

捉えられている。EW 方向では観測記録が解析結果に比べ最大值、 スペクトルともに大きめに現れる。これは当該地点が貯水池に近 接しており、局所的な地盤增幅の影響が現れたことが原因の 1 つと 考えられるが、現状では明らかではない。EW 方向の観測記録の最 大値はパルス状の波形に現れており、これを除けば、振幅レベル は解析結果と概ね整合するものと考えられる。また六甲山側に位 置する神戸大学や本山第一小学校で 2000 年鳥取県西部地震時に得 られた最大速度は $1.9 \sim 2.5 \mathrm{~cm} / \mathrm{s}$ である25)ことから、山側で推定さ れた地震動レベルは概子妥当であるものと判断される。

GSF の地震動を用いて他地点の地震動を評価し、2 次元断面の

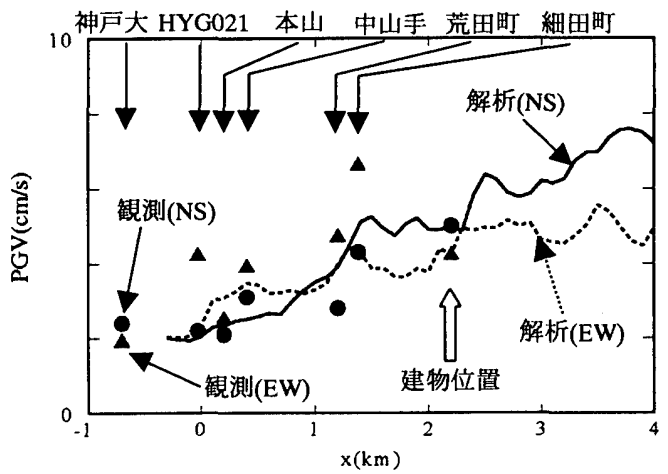

図-15 解析断面の最大速度分布と観測記録の比較

地表面で得られた最大速度分布を図一 15 に示す。FEM 領域外の工 ネルギー伝達境界より遠方の地盤応答は薄層法に基づき算出した ${ }^{26) 。}$ 同図には HYG021 のほか、建物地点近傍で観測された気象庁 27)の 地震観測点（中山手、荒田町、細田町、図一1 参照）で得られた最 大速度をプロットした。これらの観測点は解析対象断面からやや 外れた位置にあるが、深部地盤構造が 2 次元的な盆地端部構造とな っていることから、須磨断首からの距離で整理することにより最 大值分布の傾向を把握することができる。併せて六甲山側に位置 する神戸大学と本山第一小学校の最大速度も示した。観測記録に 比べやや過小評価となる地点も見られるが、全体的な分布性状は 解析により概和良好に捉えられている。海岸線に向かって大きく なる分布性状は、断層より約 $1 \mathrm{~km}$ 前後離れた領域て增幅した 1995 年兵庫県南部地震時の分布性状とはやや異なる。図-13、14 の速 度波形に見られるように、2000 年鳥取県西部地震時の地震動は 5 〜6秒程度の長周期のパルス成分を含む。単純な盆地端部構造とリ ッカー波を用いた検討 28 では、中心周期が長くなるにつれて最大分 布のピーク位置が盆地端部境界より離れる傾向を呈しており、堆 積地盤側の 1 次共振振動数とリッカー波の中心振動数が同じ場合に は、ピーク位置が盆地端部境界より堆積層厚さの 3〜4 倍離れた領 域に現れることが示されている。本ケースは概ねこの条件に対応 しており、最大分布性状の違いは入射地震動の振動数成分の差異 か現れたものと考えられる。

\section{5. 深部地盤構造が建物応答に与える影響}

深部地盤構造が高層 RC 建物の地震時応答に与える影響を検討す る。最初に GSF と図ー10 の 2 次元地盤モデルを用いて、GL1400m 位置での入射地震動を基盤波として評価した。基盤波の波 形やスペクトル特性は、HYG021 のシミュレーション波形の振幅 レベルを $1 \sim 2$ 割程度小さくしたものと類似しており、最大速度は いずれの方向も $1.7 \mathrm{~cm} / \mathrm{s}$ である。この基盤波を建物直下の地盤を成 層構造と仮定したモデル（表ー3）に入力し、地表面の地震動を算 定した。これは基盤不整形の影響を取り除いた地震動と解积する ことができる。次に図ー7の軸対称 FEM を用い、建物の SR モデ ルに入力する埋め込み杭基礎の基礎入力動を評価した。GSF に対 する基礎入力動の伝達関数を図一12(b)に示す。短周期域では入力 低減効果が見られるが、建物の 1 次固有周期近傍の 2 秒ではほぼ 1 である。基盤不整形の影響を取り除いた基礎入力動の加速度波形 と $0.1 \mathrm{~Hz}$ の Parzen ウィンドウをかけたフーリエ振幅スペクトルを 


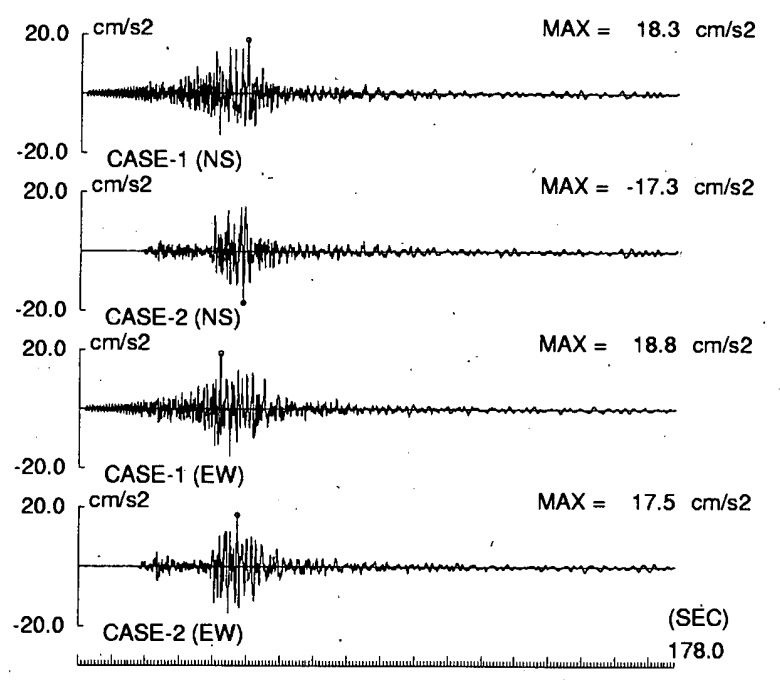

（a）基礎入力動の加速度波形
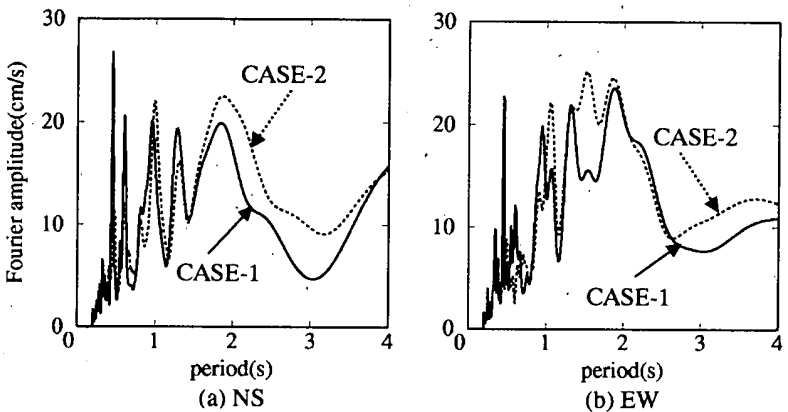

(b) フーリエ振幅スペクトル

図-16 基盤不整形の影響の有無による基礎入力動の加速 度波形とフーリエ振幅スペクトル

図-16 に示す。このケースを図中 CASE-1 と記す。また基盤不整 形の影響を含む基䃈入力動として、GSF の地震動から軸対称 FEM を用いて評価した基礎入力動（CASE-2）を同図に比較して 示す。CASE-1 の加速度波形には短周期成分がやや顕著に現れるが、 これは基盤波逆算時に短周期成分が十分に除去しきれていなかっ たことが原因と考えられる。基盤不整形の影響が含まれる CASE-2 のスペクトルは、一部逆転する周期もあるが、周期 1 秒より長周期 の成分については CASE-1 に比べ全般的に大きい。これは下方よ り堆積層を伝わる波動成分と、断層境界で励起され水平方向に伝 播する波動成分とが干渉した結果と考えられる。

これらの基礎入力動を、建物の SR モデルに入力し非線形地震応 答解析を実施した。時間刻み、剛性、減衰特性、復元力特性は 4.3 の解析条件之同じである。図-17に $36 \mathrm{~F}$ の応答加速度波形と加速 度応答スペクトルを、図一18 に最大応答層間角を示す。CASE-2 の NS 方向波形は図一9に示した観測記録の包絡形状と若干差異が 見られるが、長い継続持間は同様に再現される。EW 方向の解析結 果は観測記録と良好に一致する。一方、基盤不整形の影響を取り 除いた CASE-1 の応答波形は NS、EW 方向ともに CASE-2 や観 測記録の波形特性と異なり、応答時間が短い。CASE-1 の NS 方向 の最大屇間変形は、CASE-2 に比べ最大で $2 / 3$ 程度まで小さくなる。 CASE-1 の NS 方向の応答スペクトルは、CASE-2 や図-9(b)の観 測記録に比べ 1 次共振時のピーク值も小さく周期も短い。これは NS 方向の基礎入力動に見られる周期 2 秒前後の成分の違いが及ほ

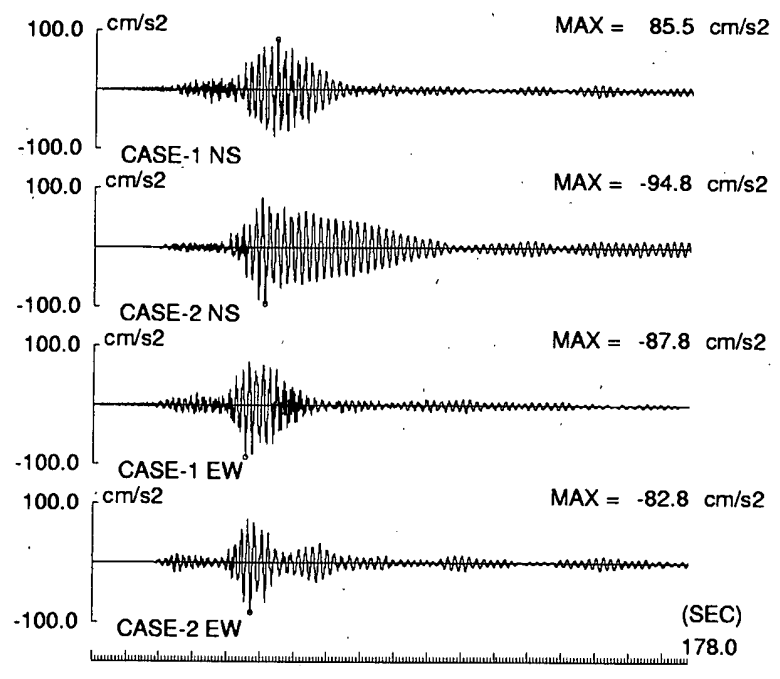

(a) 応答加速度波形

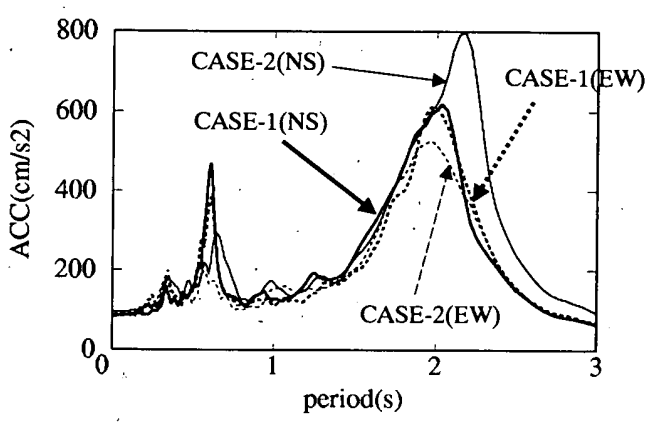

(b) 加速度応答スペクトル $(\mathrm{h}=3 \%)$

図-17 基礎入力動を用いた $36 \mathrm{~F}$ の応答加速度波形と 応答スペクトル

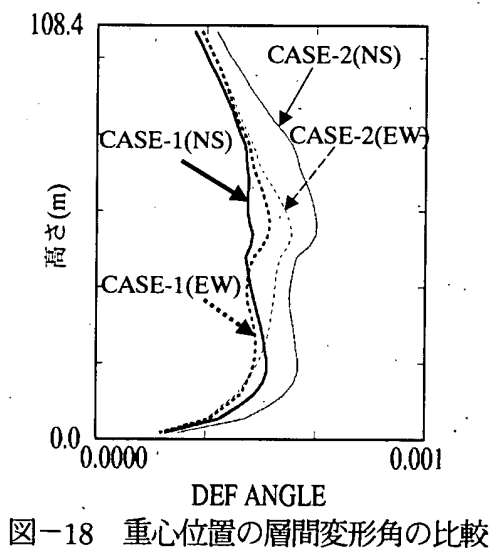

す建物の非線形性による周期変動によるものであり、CASE-1 では 建物はほぼ線形領域にあるのに対し、CASE-2 や観測記録では非線 形領域に入り、周期が 1 割程度長くなる。建物周期による応答波形 の違いを検討するために、弾性周期である周期 1.93 秒とその 1 割 増の 2.12 秒の弾性 1 質点モテルに、 $1 \mathrm{~F}$ の NS 方向の観測記録を入 力したときの加速度芯答波形を図-19に示す。减衰定数ば $1.3 \%$ と した。継続時間が短认周期 1.93 秒の包絡特性は CASE-1 に、継続 時間が長い周期 2.12 秒は CASE-2 や観測記録に対応する。両ケ 一スでの応答波形の違いは、CASE-2 や観測記録では基盤不整形 の影響により周期 2 秒前後の成分が CASE-1 に比べ大きくなり、 建物の周期が伸びたことにより応答波形の継続時間が長くなった 


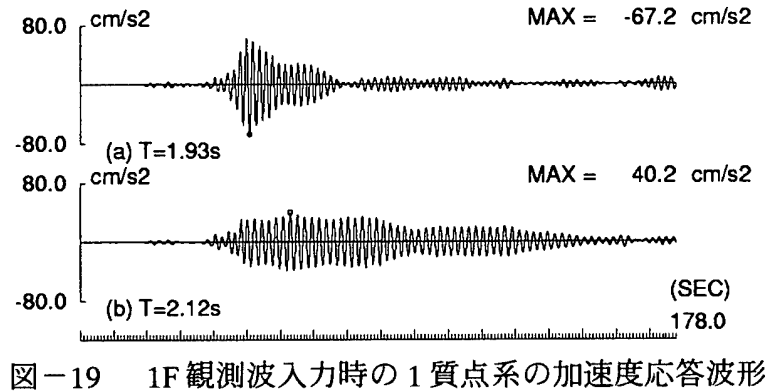

ことから生じたものと判断される。以上の解析検討から、深部地 盤の基盤不整形が地震動特性に影響を与え、建物の非線形挙動を 含む地震応答特性にも影響を及ぼしうることが示される。

大規模な地下構造調查により、多くの地域で堆積平野を含む深 部地盤構造が明らかになりつつある。これらの地盤内を伝播する 地震動に関し、盆地端部近傍での增幅や平野内を伝播する表面波 による継続時間の延伸が、高首建物の地震時応答に影響を与える 可能性がある。建物の耐震設計においては、不整形性を含む当該 敷地の地盤增幅特性を適切に反映させた入力地震動を用いる必要 があり、本検討結果はそれを示唆する事例の 1 つと位置付けられる。

\section{6. まとめ}

神戸市街地に建つ高首 RC 建物を対象に、建物内て観測された強 震記録のシミュレーション解析を行った。また 2000 年鳥取県西部 地震時に建物近傍の地表で得られた観測記録を用いて、当該地点 直下の深部地盤構造を考慮した地盤震動解析を行い、敷地内深さ $300 \mathrm{~m}$ の地中位置や他地点で得られた観測誏録との整合性を調べた。 最後に深部地盤の基盤不整形性が、本建物の非線形挙動を含む地 震応答特性に与える影響を解析的に評価した。これらの検討結果 を以下にまとめる。

(1) 建物頂部之 1 階て観測された地震記録のフーリ工振幅比から、 2000 年鳥取県西部地震の応答時には建物がやや長周期化し、非線 形領域に入ったことが分かった。次に地盤との動的相互作用を考 慮した解析モデルに1階の観測記録を入力し、シミュレーション解 析を行った。このとき $14 、 36$ 階の観測記録と整合するように、設 計用モデルをべースに建物の剛性、減衰特性、復元力特性等の調 整を行った。この結果、線形応答時、非線形応答時、いずれの場 合もほぼ良好に観測記録を再現することができた。

(2) 当該建物敷地内の地表面で得られた観測記録と盆地端部構造 を呈する直下の深部地盤構造を用いて、GL-300m 位置で同時に観 測された地震記録や、山側地点で観測された強震記録のシミュレ 一ション解析を行った。この結果、観測による速度波形やスペク トル特性が概る良好に再現され、断層に直交する解析断面の最大 速度分布も観測記録の傾向と整合した。

(3) 深部地盤構造における基盤不整形の影響を取り除いた入力地 震動を評価し、これを建物モデルに入力することにより、基盤の 不整形性が建物応答に与える影響を評価した。この結果、加速度 波形や最大層間変形角が観測記録やシミュレーション結果と異な り、深部地盤の基盤不整形による地震動增幅か湕物の地震時応答 に影響を及ぼすことを示した。

\section{謝辟}

本研究は都市基盤整備公団と鹿島による共同研究の成果であります。深 さ $300 \mathrm{~m}$ 位置の強震観測は、独立行政法人・建築研究所之共同で実施し たものであります。建築研究所、鹿嶋俊英氏には強霞観測に関する 有益な情報を頂きました。また本研究ではK-net、気象庁、関西地震観 測研究協議会による観測記録を使わせていただきました。これらの地震観 測や記録の提供に携わった関係各位に感謝いたします。 2 名の査読者より 頂いたコメントは、本論文を修正する上で有益でした。

参考文献

1) 日本建築学会近畿支部鉄筋コンクリート構造部会 : 1995 年兵 庫県南部地震コンクリート系建物被害調査報告書、1996

2) 林康裕、宫腰淳一、田才晃、大野義照: 1995 年兵庫県南 部地震における RC 造建物群の耐震性能、日本建築学会構造系 論文集、第 528 号、pp.135-142、2000.2

3）阪神大震炎 (兵庫県南部地震) 調查報告、竹中工務店、pp.206217. 1995

4）条村 匡、田中幹夫、此上典文、中村 充、日下部馨：兵庫県 南部地震における新長田駅前高層 SRC 造建物の解析的検討、 日本建築学会大会学術講演梗概集、構造 II ,pp.533-538、1996

5) 安井譲、井口道雄、赤木久真、林康裕、中村充 : 1995 年兵庫県南部地震における基礎有効入力動に関する考察、日本 建築学会構造系論文集、第 512号、pp.111-118、1998.10

6) 永野正行、大野晋、古山田耕司、加藤研一: 兵庫県南部地震 時の神戸市内における基盤地震動および地盤增幅特性、日本建 築学会構造系論文集、第 511 号、pp.77-84、1998.9

7) Kinoshita, S: Kyosin Net(K-net), Seismol. Res. Let., 69, No.4, pp.309-332, 1998

8) 青井真、堀賁喜、笠原敬司: Hi-net(4) : 基盤強震観測網 (KiK-net)、日本地震学会 2000 年度秋季大会講演予稿集、P007、 2000

9）柳澤信行、高橋良典、福本晃治：大阪市域の高首建物における 鳥取県西部地震観測とそのシミュレーション解析、日本建築学 会大会学術講演梗概集、構造 II , pp.523-530、2001

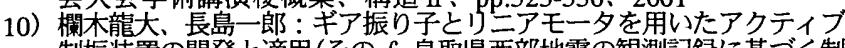
制振装置の開発と適用(その 6 鳥取県西部地震の観测記録に基づく制 振効果 (検証)、日本建築学会大会学術講演梗概集、構造 II pp.459-460、2001

11）加藤研一、山添正稔、武村雅之: 中国・四国地方を対象之した KiK-net 地中埋設地震計の設置方位の推定一鳥取県西部地霞、 芸予地震の強震記録に基づく検討一、地震第 2 輯、第 54 巻、 pp.421-429、2001

12）高橋元美、福澤栄治、磯崎 浩 : 高層 RC 造骨組の柱の変動軸 力を考慮した等価曲げせん断壬デルよる地震応答解析、構造 工学論文集、Vol.39B、pp.147-154、1993

13) 磯崎 浩、福澤栄治、高橋元美: 柱の変動軸力と 2 軸曲げモ一 メントを考慮した RC 造立体骨組の弾塑性地震応答解析、日本 建築学会構造系論文報告集、第 441 号、pp.73-83、1992.11

14) Tyson, T. R. and E. Kausel: Dynamic Analysis of Axisymmetric Pile Groups, Massachusetts Institute of Technology, Department of Civil Engineering, No.751, 1983

15) 辻条勝彦、三木幹夫、当島俊英、荒川総一郎、阿部秋男 : 神戸 市兵庫付近の深層ボーリング結果について、第 32 回地盤工学 研究発表会、B-0、pp.57-58、1997

16）白本建築学会：鉄筋コシクリート造建物の勒性保証型耐震設計指針 (案) ・同解説、pp.38-40、1997

17) 日本建築学会：建築物の耐震設計資料、p.275、1981

18）白本建築学会: 建築物の減衰、pp.137-143、2000

19）林康裕：地震被害から見た地震荷重、pp.2-11、地震動と地霞荷 重を聚ぐ二現状と将来の課題一、2002 年度日本建築学会大会 構造部門（振動）パネルディスカッション資料、2002.8

20) 永野正行、工藤一嘉、武村雅之: 神戸市長田区における地下構 造の不整形性を考慮した 1995 年兵庫県南部地震 $\left(\mathrm{M}_{\mathrm{J}}=7.2\right)$ の余震 アレイ観測記録のシミュレーション解析、地震 $2 、 52 、$ p 2 .2541、1999

21）関西地盤情報活用協議会：新関西地盤、神戸および阪神間、 1998

22）佐野正人 : 大阪盆地の内部構造之伏在活断層、大阪盆地の内部 構造と伏在活断層・地盤・強震動・" 震災の带”、断層研究資 料セシタ二第 11 回セミナー、pp.6-23、1998

23) 神户市、建設工学研究所 : 防神・淡路大震災と神戸の活断層、 1998

24) 防災科学技術研究所：強震ネットワーク、http://www.knet.bosai.go.jp/k-net

25）関西地震観測研究協議会事務局：、関西地震観測研究協議会 地震記録 CD-ROM 資料集、2001

26) Lysmer, J. and L. A. Drake: A Finite Element Method for Seismology, Methods in Computational Physics, 11, pp.181-216, 1972

27) 気象庁：95 型震度計波形デー夕 (平成 12 年鳥取県西部地震) 気象業務支援セン多ー、2000

28）永野正行: 2 次元盆地端部構造の地震動增幅と表面波の干渉、 日本建築学会構造系論文集、第 552 号、pp.85-92、2002.2 